\title{
KAZAKH DIASPORA IN KYRGYZSTAN: HISTORY OF SETTLEMENT AND ETHNOGRAPHIC PECULIARITIES
}

\author{
Bibiziya Kalshabayeva \\ Professor, Department of History, Archeology and Ethnology \\ Al-Farabi Kazakh National University \\ Almaty, Kazakhstan \\ Email:kalshabaeva_b@mail.ru
}

\section{Gulnara Dadabayeva}

Associate Professor, KIMEP University

Almaty, Kazakhstan

Email: gdadabaeva@mail.ru

\author{
Dauren Eskekbaev \\ Associate Professor, Almaty University of Management \\ Almaty, Kazakhstan \\ Email:d.eskekbaev@mail.ru
}

\begin{abstract}
The article focuses on the most significant stages of the formation of the Kazakh diaspora in the Kyrgyz Republic, to point out what reasons contributed to the rugged Kazakh migration process in the nineteenth and twentieth centuries and how it affected the forms and types of their settlements (compact or disperse). The researched issues also include the identification of factors provoked by humans and the state to launch these migrations. Surprisingly enough, opposite to the claims made by independent Kazakhstan leadership in the early 2000s, the number of Kazakhs in Kyrgyzstan wishing to become repatriates to their native country is still far from the desired. Thus the article is an attempt to find out what reasons and factors influence the Kazakh residents' desire to stay in the neighboring country as a minority. To provide the answer, the authors analyzed the dynamics of statistical variations in the number of migrants and the reasons of these changes. The other key point in tracing what characteristic features separate Kazakhs in Kyrgyzstan and their kinsmen in Kazakhstan is the archival data, statistical, historical, and field sources, which provide a systematic overview of the largely unstudied pages of the history of the Kazakh diaspora.
\end{abstract}

Keywords: Kazakh diaspora, Kyrgyzstan, migration history, oralman ${ }^{1}$ repatriates, population size, settlement 


\section{INTRODUCTION}

The diaspora has played a significant role in the foreign policy of Kazakhstan, which aims at stressing the continuity of the unity that is said to exist among all the Kazakh people. The Kazakhs living abroad ${ }^{2}$ are an essential target for the republic's foreign policy, as far as the relations with neighboring republics are concerned. They often keep strong ties with their historical motherland. Different historical, cultural, political, and economic reasons, which made them leave the homeland, have determined their current residential status. This status also depends on their country of residence's foreign policy and relations with Kazakhstan. Since its foundation in 1991, Kazakhstan has been trying to position itself in the international arena as a democracy-oriented state respected by the global community. Consequently, this vision determines how Kazakhstan chooses the ways to either support or neglect interests of kinsmen abroad. Fierce disputes about what constitutes the Kazakh diaspora abroad characterized the academic debate in Kazakhstan in the 1990s and early 2000s (Mendikulova 1997). Finally, Kazakhstan's scholars have adopted something that approaches a consolidated definition of diaspora close to Gabriel Sheffer's definition: "Modern diasporas are ethnic minority groups of migrant origins residing and acting in host countries but maintaining strong sentimental and material links with their countries of origin - their homelands" (Sheffer 1986: 3).

Unfortunately, the current level of historical research covering the problems of the formation of the Kazakh diaspora and the main periods of its history is far from satisfactory (Mendikulova 2006; Koblandin 2008; Tatimov 1992), although there is an obvious need for such research. Among the most pressing challenges of modern studies is the problem of the formation of the Kazakh diaspora in Central Asia, including the neighboring Kyrgyzstan. This topic did not get enough attention in the national and foreign historiography due to various reasons (Kalshabayeva 2014). During the Soviet period, this research topic was an implicit taboo. On the other hand, there was an upsurge of scientific interest in ethnic problems, particularly diaspora studies, after the postSoviet republics (including Kazakhstan) gained their sovereignty, leaving the theoretical basis of such research in chaos.

Before the country gained independence, the Kazakhs living abroad had not been studied as a diaspora in a foreign environment. However, Russian and foreign researches conducted in the eighteenth and nineteenth centuries had come up with significant information that covered the issue of Kazakh settlements since ancient times. The famous Russian traveler Peter Pallas (1778) acquainted his readers with the population and ethnic composition of Kazakh settlements in the Turkestan region. P. Pashino (1868) continued to explore the southern region and focused in particular on the Tashkent region: his papers 
contained data about the Chirchik Kazakhs, their households, anthropological type, etc., while N. Grodekov's (1889) works mainly presented the Kazakhs of the Tashkent uyezd (district) and their life and culture. R. Karutts (1910) described Kazakh life and material culture in Mangistau and Turkmenistan. V. Masalsky (1913), on the contrary, focused more on the economic structure and material life and handicrafts of the Kazakh tribes that populated the Turkestan region. Russian travelers and scholars were primarily interested in defining new territories, the native population's culture and their economy to later serve as a repository of scientific data.

The work done during the Soviet period differs from the previous approaches adopted by Russian scientists, which constituted collecting data for exploring historical roots, reasons of migration, and factors affecting the direction and intensity of Kazakhs' movements into neighboring lands. Soviet ethnography had faithfully served the state's interests, especially during the delimitation of the borders of the Asian republics in the 1920s-1930s. The Academy of Sciences of the USSR organized numerous expeditions that continued collecting field materials covering these issues (Materials 1927). Some information was gathered during the expeditions dedicated to the zoning of Uzbekistan (Materials 1926). Later on, Soviet ethnologists continued researching Kazakh migration and settlement problems in Central Asian republics (Arkhipov 1930), touching also upon the most sensitive questions of co-existence of different ethnic groups in the lower reaches of the Syr Daria River basin, including Kazakh tribes inhabiting Karakalpakstan (Shalekenov 1966). Kazakh people had been living close to Kyrgyz tribes in the Zhetysu Oblast long before the border delineation between the Central Asian Soviet republics started (All Central Asia 1926). The most important information covering Kazakh people's life in Kyrgyzstan can be found in the "Review of the Semirechye Region" (Yearbook 1924), in Masalsky's work "Turkestan Region" (Masalsky 1913), and in the materials of the statistical committee of the Turkestan region.

In the post-Soviet period, M. Sartbayev (2009), K. Koblandin (2012), K. Baltabayeva (2011), B. Kalshabayeva (2011), and other local scholars researched this topic. Sartbayev mainly investigated the historical reasons for the formation of the Kazakh diaspora in Kyrgyzstan, while Koblandin focused on its ethno-demographic composition. Baltabayeva and Kalshabayeva analyzed the census data that had been collected in Kyrgyzstan since 1991, when the republics declared their independence. Kalshabayeva devoted a special chapter in her monograph on the issues of Kazakh settlements, the size of the Kazakh population and its dynamics, along with the ethnic history of the Kazakh tribes.

The migration of the Kazakhs from their historical motherland was caused by many historical events and catastrophes. The most significant movement of the Kazakh tribes into neighboring territories took place due to the hardships of the Dzungar-Kazakh wars, particularly in the early eighteenth century. Kazakh 
people still remember the 'Years of Great Calamities' (1723-1727) which brought with them famine, terrible sufferings, and destruction of their traditional economic life. A split between the zhuses (hords) of the Kazakh Khanate was accompanied by a catastrophic dissent among their political elite about how to politically engage the neighboring states. The political situation was still worsened by the Kazakh, Bukhara, and Kyrgyz inconsistency in actions, and a sudden attack from the Oirat (Dzungar) side ended with a catastrophic defeat of some Kazakh tribes. Later on it led to the seizure of the settled oases along the Syr Darya River, which forced the Kazakhs to leave their lands. Further migrations followed due to the colonization policy of the tsarist government and the settlement movement of the Russian peasantry from the central part of the Russian Empire. Kazakh participation in the 1916 uprising was brutally suppressed by the Russian authorities and was followed by a next wave of migrations. In the Soviet period, the last substantial migration wave occurred due to the great famine of 1932-1933 (Kalshabayeva 2014).

\section{THE RESEARCH OBJECT}

Our research object is the history of the formation and the ethnographic peculiarities of the Kazakh diaspora in Kyrgyzstan. Since Kazakhstan declared its independence in 1991, the country's political leadership, namely the first president Nursultan Nazarbayev (1991-2019), persistently worked to establish and strengthen ties with Kazakh kinsmen living abroad (Mendikulova 2006: 80). The situation of Kazakh people in Kyrgyzstan was among the urgent problems discussed in the republic's media. In 1999, statistical data of the Kyrgyz Republic showed that the number of Kazakhs was 42,657 (Statistical Data 2001), while by 2009 this number had decreased to 33,200 (Kalshabayeva 2011). Here we try to analyze the main reasons for the change in the number of Kazakh population in Kyrgyzstan. Some scholars insist that the main characteristic of Kazakhs is their ability to adapt successfully to any new environment (Svanberg 1989), which gave us a reason to focus on the causes of variation data. Meanwhile, the Kazakhs are strongly inclined towards keeping their traditional foundations such as tribal belongings, customs, and language. Svanberg, when characterizing the Kazakh diaspora in Turkey, stresses: "Strong and self-conscious Kazakh group identity continues to exist even under changing conditions of new environment with everyday new rituals, usage of new technologies, alien economic system, new pace of work and gustatory habits" (Svanberg 1989: 211). 


\section{MATERIALS AND METHODS}

The authors used a number of archive findings, for instance, materials of collections 847, 21, and 105 from the Central State Archive of the Kyrgyzstan Republic, which includes valuable information about the history of migration and the settlements of Kazakh people in Kyrgyzstan. For instance, collection 847 of the Special Commission for Land Management contains materials on the forced migration that led Kazakhs ${ }^{3}$ to leave their lands, and measures taken by the government to return them to their former place of residence. Having analyzed these documents, the authors faced problems such as the diversity of causes of Kazakh migration from Kazakhstan that had started from the second half of the nineteenth century and lasted until the end of the Great Famine of 1932-1933. The main reasons that drove Kazakhs to leave their lands were the tsarist state's policy since the colonization of the Kazakh territory by the Russian Empire, which was accompanied by rangeland seizures. Later, the national liberation movement of 1916 was brutally suppressed by the Russian colonial authorities, which led to the outflow of 100,000 Kazakhs into China. However, some Kazakhs stayed in Kyrgyzstan to escape the hostility of the Chinese side. The Russian tsarist authorities, namely the general-governor of the Turkestan region, A.N. Kuropatkin, claimed that the national liberation movement of 1916 had been supported by the Chinese, which led to bitter disputes between Russians and the Chinese. Finally, the Russian administration, due to numerous petitions of Russian and Kazakh politicians and intelligentsia, was asked to declare an amnesty for all Kazakhs and Kyrgyz to give them an opportunity to return to the Semirechye (Zhetysu) region. The second reason that drove Kazakh migration out of the republic was the Soviet policy of collectivization, which finally led to famine in the early 1930s. It was mainly state policy that affected Kazakh migration and there were various reasons why Kazakhs, instead of heading towards neighboring China, preferred to stay in Kyrgyzstan.

The Central State Archive of the Republic of Uzbekistan also contains ubiquitous materials concerning the Kazakh "migration" that had been caused by the delineation of the borders between the Central Asian republics in the 1920s and 1930s and the subsequent destiny of Kazakh settlements. Some of the Kazakh families preferred to move to Kazakhstan while mostly they continued their traditional life in the newly established Kyrgyz Soviet Republic. Collection p-1 (State Archive of Uzbekistan) contains materials on controversial issues of rangelands usage. In 1926 an order of pasture use was adopted, namely for grazing dzhaylyau Susamyr ${ }^{4}$ in the Kyrgyz Republic, which defined that this pasture in the Kirghiz Autonomous Region was provided for the nomadic population of the Kazakh Republic to be used for summer grazing in 1926 and as summer pastures on the following grounds: a) People must roam to pasture 
Susamyr and run the cattle along the cattle roads Kok-Kiya, Kupre, Chabyr, and Utmek and all the cattle heading from the Kazakh Republic to the Kyrgyz Autonomous Region must have the appropriate veterinary certificate from veterinarian stations in the residence points. Cattle grazing on pasture Susamyr is not permitted without these certificates; b) The cattle owned by the citizens of the Kazakh Republic, passing along the road defined in paragraph 1, across state-owned lands and forest cottages are exempt from fees for grazing and cattle driving under the condition that the cattle stay on the road for no more than two weeks. In the case of running cattle across pasture Susamyr or other roads, but not the roads and passes specified in paragraph 1 , section a, livestock owners pay 20 kopecks per head of the horned cattle, and 10 kopecks per head of the small cattle to field or forest guards (CSA RU, F.r-1. op.1. d. 707. pp. 94-95).

The methodological arsenal of the research includes as scientific methods interviews and analysis of questionnaires of more than 60 informants living nearby Bishkek ${ }^{5}$ and surrounding regions. However, in this paper information of 12 interviews and questionnaires was used. This choice was determined by the compact character of the Kazakh settlements in this part of the Kyrgyz Republic, such as the villages Manas, Razdolnoye, Altybarak, and others. All respondents agreed to be interviewed and voluntarily answered the questionnaires. The selection of informants was based on the "snow ball" principle in places of compact settlements of Kazakhs in Kyrgyzstan. These materials were collected during fieldwork in Kyrgyzstan in 2000-2001 and in 2009-2011, in the neighboring Bishkek districts - Alameddin, Sokuluk, Talas, Shu, and others. All materials were classified according to tribal composition, economic activities, family customs and traditions, and the compact character of the Kazakh settlements. The authors also used complex historical methods such as the principle of historicism, analytical-comparative methods, and comparative-historical methods. The historicism principle was used to identify the main stages of the formation of the Kazakh diaspora in Kyrgyzstan beginning in the nineteenth century. Ethnographic peculiarities of the Kazakh diaspora were researched on the basis of analytical-comparative methods to highlight the differences between the local population and Kazakh settlers. The following research methods were used: ethnographic field research, interdisciplinary research along with the comprehensive analysis of population, resettlement and repatriation of oralmans to their historic homeland. Therefore, the historical-comparative analysis focuses on the problems of population dynamics of Kazakhs and the identification of social and political factors that caused population growth or decline. The correlation analysis is applied to the classification and systematization to select main political and socio-economic factors contributing to the Kazakh repatriation from Kyrgyzstan. 
The main research problem that initiated this study is the question about how far the success of representatives of the non-titular Kazakh ethnic group in Kyrgyzstan contributed to curbing their desire to return to their homeland. On the way towards social adaptation in the new country there are cultural and psychological barriers to become a full-fledged citizen of the country while being able to keep another ethnic identification. J. Berry (2003) suggested defining the social-cultural adaptation of migrants in correlation with the following factors: 1 ) cultural proximity between home country and new environment; 2) the number of contacts between newcomers and local population; 3) what activity migrants are involved in in the receiving country; and 4) the ability to speak the languages of the receiving country. Kazakhs' adaptation had run comparatively smoothly due to significant similarities of culture and economic life of the Kyrgyz and Kazakh people. Also, Kazakh people were living and continue to live in compact settlements near Bishkek, which has helped them to maintain their traditional economy (cattle-breeding system) and a strong ethnic identity.

\section{ON THE PROBLEM OF THE KAZAKH DIASPORA FORMATION IN KYRGYZSTAN}

The historical events of the 1916 national-liberation movement became one of the main reasons that promoted the formation of the Kazakh diaspora in Kyrgyzstan. The documents found in the Central State Archive contained materials to prove this hypothesis.

The 1916 events in the former Zhetysuyskaya Oblast ${ }^{6}$ or the so-called Kyrgyz revolt ended with an outflow of large groups of the Kyrgyz abroad, to neighboring China. Almost all people living in the Karakolsky uyezd ${ }^{7}$ (parish) and in five volosts of the Narynsky uyezd, i.e., more than half of the population left their native lands. The big Sarybagyz volost, which is in Pishpek uyezd, and most of the inhabitants of Shamsin and Tykaevskaya, did the same as did the Kyrgyz people from Alma-Ata, Lepsinsk, and Kapal. (CSA RK, F.847. op.1. d. 27. L.136-136 obr.)

Unfortunately, the exact number of refugees is still impossible to determine. However, we estimate this number as approximately 100,000 people. All of them fled to western China, mainly to two districts: Ili with its center in Kuldzha and Kashgar-Uch Turfan with such urban centers as Uch Turfan and Aksy. A Chinese state representative, A. Saltanaev, reported to China the following estimates of Kazakh refugees to the Ili district: "Up to 300 families from Lepsinsk, about 150 families from Kapal, 400 families from Zharkent, and 210 
families from Karakol, while Pishpek accounted for eight families. In total there are 1068 families" (CSA RK, F.847. op.1. d. 27. L.136-136 obr.).

Due to the terror of the Reds and partisans fighting for the Soviet power in 1917-1918, the next waves of Kazakh refugees followed the previous movement to the Chinese territories. Their fear was rooted in the events of 1916, when rich and prosperous Kazakhs were terrified by the news about the possible confiscation of their cattle and lands.

The Chinese authorities were certainly not happy about these unexpected movements and used all the possible means to force the Kazakhs to migrate either back to Kazakhstan or to the territories of the neighboring countries. As archival materials show, they oppressed the Kazakh newcomers, and humiliated them to prevent their settlement on the Chinese land. State commissioner Belen Sanayev, in his report addressed to the Chair of the Kyrgyz Executive Committee ${ }^{9}$ Zelensky, states:

The situation with the Kazakh refugees is awful. They were unable to get accustomed to the new environment. The pressure of negative factors forced them to sell the Kyrgyz and Kara-Kyrgyz into slavery. Many Kazakh women got married to the Chinese by mistake because they confused them with Muslim Dungans. Later, when they discovered their mistake, some of them complained to the Chinese authorities. In response, the Chinese administration ordered to cut off their tongues. Moreover, women who tried to leave their Chinese families were beaten or executed (murdered) by state authorities. There were cases where Chinese spouses, after marrying Kazakh women, later got married to their daughters when they reached the age of 12. Many desperate women committed suicide by rushing into rivers. (CSA RK, F.21. op.3. d. 105. L. 6-7 obr.)

The Soviet government, after receiving a number of reports from the local authorities of the Kazakh Republic, decided to act decisively and start the process of repatriating refugees from China. During the spring of 1918, the first migrants from China came back to their native lands. The process of repatriation was difficult and long; it lasted until 1921/22 when the Soviets launched their land reform. Because of the confiscation of property, many Kazakhs were afraid of returning and preferred to stay in the Kyrgyz territories. The fears of the Kazakh people can be explained by their experience of the punitive colonial policy of Russia, as after the revolt of 1916, the general-governor of the Turkestan region, Kuropatkin, had initiated a wave of confiscation of the Kazakhs' lands. The Provisional Government, during 1917, was unable to solve this problem and later, during the civil war, the complaints of Kazakhs were left unanswered. Field materials collected by one author during her expeditions confirmed the validity of these considerations. For instance, one of the informants, Kasen 
Abdyganiev, told stories about how his ancestors had settled in Kyrgyzstan after leaving China. Kyrgyz manaps ${ }^{10}$ provided significant assistance for Kazakh refugees: they received cattle and pastures in Kyrgyz lands (Kaliyev Bugibay, Field materials 2000).

Two trends affected the Kazakh migration dynamics in the early 1920s: the influx of the Russian population and the return of Kazakh-Kyrgyz people who had escaped to China after 1916. During four months in 1921, the total number of Kazakh repatriates reached 517 while in Kyrgyzstan the number reached 307. As chair of the Zhetysu district executive committee, Kudebayev, said, 'during the period June-December 1925, 67 families (372 people) were evacuated to Semirechye, and the number of Kyrgyz families is estimated to be 65, i.e., 363 people (Kalshabayeva \& Seisenbayeva 2013). Between March 23 and June 1, four Kazakh families (eight people) arrived in Pishpek Okrug, six Kazakhs arrived in the Almaty uyezd, while Karakol received five Kazakhs (CSA RK, F.847, op.1, d. 27, pp. 128-129).

The Kazakh diaspora in Kyrgyzstan added new migrants when Kazakhs of the Argyn tribe decided to migrate in search of new pastures. The issue of delineation of the borders of the Central Asian republics also brought up discussions about the territories of the ethnic groups. Later, these measures led to Kazakh mass migration into Kyrgyz-populated lands. Demarcation of the borders also raised issues related to pasture (dzhaylyau) assignments. Among the disputed areas were such pastures as "Tracts Susamyr", "Han Dzhaylyau", and "Karkara". ${ }^{11}$ For instance, shortly before the revolution of 1917, the Susamyr region, located in the northern part of the Kyrgyz Autonomous Region, was jointly used by Kazakh nomads and Kyrgyz cattle breeders from the Aulie-Ata district, which later became part of Kazakhstan.

The Susamyr pasture became the object of heated debates due to its location. Those Kazakhs who were interested in using Susamyr pastures had to drive cattle from their winter camps hundreds of miles through two volosts ${ }^{12}$ and over two high ridges (the Alexander and Talas ridges). This only paid off for the cattlemen who had thousands of cattle in their herds, whereas for small herders driving cattle over long distances was unprofitable. Moreover, by the decision of the Central Executive Committee from May 3, 1927, dzhaylyau Susamyr and other pastures went into the possession of the Kyrgyz region. This fact also led to the growth of the Kazakh diaspora in Kyrgyzstan.

Demarcation of the territory between Kazakhstan and Kyrgyzstan also caused disputes concerning the Kazakhs living in the area of Atbashi of the Pishpek uyezd. Here is the translation of the document signed by Argyn Kazakhs to confirm their right to possess this land, addressed to the Land Management Committee of the Kyrgyz ASSR: 
The Land Code states that land should belong to those who cultivate it and live on it. We, the Argyn-Kazakhs, from Akmola and Karkarala uyezds, arrived in the Pishpek uyezd forty years ago as workers/laborers and shepherds. We have settled in Atbashi and since this time we have been living here. This fact is confirmed by the surveyor's act from the Frunze land surveying group on June 4, 1926. Copies are attached here. (CSA RK. F.21.op. 1. S.5. L. 61.63)

They continued with complaints that they had had to wait until 1928 to solve all the disputes over land plots.

By the Decree of the Presidium of the Central Executive Committee, issued on July 23, 1928, the border between Kyrgyzstan and Kazakhstan was established. It determined "the boundary along the Chu River as follows: from the western part of the Kamyshanovsky village crossing through its territory, ${ }^{13}$ then down to the Chu River and upstream the river to the village of Argyn, bending it from the south ${ }^{14}$ and then upstream the Chu River, etc." (CSA RU, F. r-1, op.1, d. 707, pp. 95-96).

Such demarcation boundaries of the village Argyn cut its inhabitants off from Kazakhstan.

The inhabitants of Argyn, numbering 42 households, ${ }^{15}$ made complaints to the authorities with a request to settle them in another part of Kyrgyzstan and to grant them citizenship (CSA PK, F. 21 op. 3, d. 26 L. 39-40). According to the archival documents, this request was discussed at the meeting of the Central Administrative Commission (NKVD of the Kazak ASSR) on November 16, 1928. The Commission adopted a resolution to satisfy Argyn-Kazakhs' request, in order to provide economic benefits for the dwellers of the village (water was delivered from the side of the Kyrgyz Republic) and due to the strong desire of Kazakhs to change their citizenship (CSA RU, F. r-1, op.1, d. 707, pp. 95-96).

In the period from 1926 to 1939, the population of Kyrgyzstan increased by 456,500 and was estimated to be $1,458,200$. The influx of the population to the republic resulted in an average annual increase of 3.9 percent. This figure was three times higher than data for the pre-revolutionary period shows. The average annual increase of the Kyrgyz population was 1 percent, while the growth of the other ethnic groups was estimated as follows: Russians 13.3 percent, Uzbeks 3.1 percent, Ukrainians 9.5 percent, Germans 14.4 percent, Tatars 25.6 percent, Kazakhs 104.5 percent, and Tajiks 6.7 percent (Zhelokhovtsev 1989). Russian Germans also lived on the territory of Kyrgyzstan. The number of Kazakhs in Kyrgyzstan on December 17, 1926, was estimated to be 1,749 (0.2 percent) while on January 17, 1939, the number of Kazakhs reached 23,925 (1.7 percent) (CSA RK, F. 21, op. 5, E. 6, p. 109).

The next large flow of migrants from Kazakhstan and Siberia entered the Kyrgyz lands in 1932-1933, when people were severely suffering from the 
consequences of collectivization, such as famine, crop failure, food shortages, and other difficulties. Migration processes significantly changed the ethnic composition of the republic. By 1939, the indigenous population of Kyrgyzstan experienced a relative decrease to 51.7 percent, while other ethnic groups relatively increased. For instance, the Russian population increased to 20.8 percent, and the Kazakh population to 1.6 percent (CSA RK, F. 105, op. 31, D. 324, p. 47).

An increase in the number of Kazakhs in Kyrgyzstan was also caused by labor migration in search for better incomes in the 1960s and 1970s. During these two decades, due to the circumstances mentioned above, 21,263 people migrated from Kazakhstan to Kyrgyzstan, among them 486 Kazakhs who migrated to Issyk-Kul, 108 to Naryn, and 2,439 to Osh. The composition of migrants from Kazakhstan by regions of origin is as follows: 1,163 people migrated from the Aktobe region, 852 from Almaty city, 1,345 from the wider Almaty region, and 1,330 from eastern Kazakhstan. However, the largest number of migrants came from the territory of Dzhambul Oblast - 5,469 people ${ }^{16}$ (CSA RK, F. 21, op. 1, S. 5, p. 61.63).

The process of formation of the Kazakh diaspora in Kyrgyzstan covered a long period in history. Each stage of this process was characterized by particular driving factors. The authors have made an attempt to determine the different periods in the history of the formation of the Kazakh diaspora and the driving factors and reasons for migration. However, it was an extremely complex, multifaceted process that formed the modern Kazakh diaspora in Kyrgyzstan.

\section{ABOUT THE HISTORY OF SETTLEMENT AND POPULATION DYNAMICS OF KAZAKHS IN KYRGYZSTAN}

Under the colonial administration of tsarist Russia, Aulie-Ata, Bishpek, and other uyezds were part of Zhetysuyskaya ${ }^{17}$ Oblast. This was for the convenience of the territorial-administrative governance. The Russian administration never had a particular ethnic demarcation of these territories in mind. Traditionally, the Kazakhs of Kyrgyzstan had been living on the territory between the Balkhash and Issyk-Kul lakes. For instance, the statistical yearbook specified that in the Pishpek uyezd, Prigorodnaya volost, 556 households had a total of 2,477 people. Kazakh households were divided between different uyezds in the following way: four households in Naryn and 48 households in Pishpek (Yearbook 1924: 146-147).

The first national census was conducted by the Russian authorities in $1897^{18}$ to determine the size, ethnic composition, and employment of the Kazakh and Kyrgyz population. In 1897 the territories of modern Kyrgyzstan were included in Semirechenskaya Oblast of Turkestan General Governorship. Comparison 
of the data provided by the 1897 census and a second census conducted in 1913 show a significant growth of the Kazakh population in Kyrgyzstan: the respective figures were 663,000 and 863,900 (Zhelokhovtsev 1989).

In the period from 1871 to 1896 , the Russian administration continued to change the boundaries of Zhetysuyskaya Oblast, which consequently touched the area of the Pishpek uyezd. The census results indicated that Kazakh people were also living in this uyezd. Initially, the lands of the Kazakh population were joined to the Vernyui uyezd and later on their territories were again transformed into the Pishpek (Tokmak) uyezd (Krongardt 1989).

Territorial changes became the main factor that had naturally led to the formation of the Kazakh diaspora in Kyrgyzstan. Kazakhs preferred to stay in that area and continue to populate it. The fact that Kazakhs have lived in Kyrgyzstan, including Naryn Oblast, for a long period, is confirmed by numerous archival documents. Thus, one of the archival documents describes how Kazakhs reacted to the census conducted by the Russian colonial administration:

On May 5, 1909, while the census was conducted, the Kyrgyz ${ }^{19}$ from the Naryn Volost attacked A. Lutin, and he was left badly injured. Although the Kyrgyz do not present any special risk, their actions can cause some damage and undermine the authority of the Russian administration. Due to this consideration they should be sent to Akmola. (CSA RU, F.1. op.4. d. p. 1390. 2.9.)

The Kazakh population's living conditions and their settlements in the IssykKul region are described in the Central State Archive of the Republic of Kyrgyzstan (F. 21, op. 3, d. 105, p.6.) as follows: "|The Issyk-Kul basin of Aksu was a convenient area for Kazakh settlements, whereas Zauka was not of particular interest, except as an object of agriculture. Kazakhs mostly migrated between Aksu and Topay."

Unfortunately, before the 1917 revolution, information about the number of Kazakhs and Kyrgyz was reported under the common term "Kyrgyz", which makes it difficult to determine the exact number of Kazakhs. These ambiguities in the calculation of the population can be seen while analyzing several archival documents. The document dated 1927 noted that in 1926, 14,324 Kazakhs lived on the territory of Kyrgyzstan, whereas in May 1927 only 1,766 Kazakhs lived there (CSA RK, F. 21, op. 3, d. 105, p. 6). Such discrepancies can be explained by migrations and demarcation of rangelands that took place in the republic.

All censuses conducted before 1926 contained information about shalaKazakhs ${ }^{20}$. These were mainly the descendants of mixed marriages, often between Kazakhs and Sarts or Kazakhs and representatives of other ethnic groups. About 469 shala-Kazakhs had been living in Aulie-Ata before 1926. Their descendants, who now live in Kyrgyzstan, declare themselves as Kyrgyz 
and those who live in Kazakhstan as Kazakhs. However, the collected field data shows that by anthropological, linguistic and cultural features they merge with Kazakhs. Field studies confirm that some representatives of shala-Kazakhs called themselves Kazakh by origin. These factors also contributed to the increase of the Kazakh diaspora.

The ethnic structure of the Kyrgyz Autonomous Region in 1926 was as follows: 4.6 percent of Kazakhs, 44.8 percent of Kyrgyz, 4.2 percent of Uzbeks and 41.4 percent of Russians. In the Karakol-Naryn region, before 1917 the share of Kazakhs was estimated to be 1.8 percent, that of Kyrgyz 71.8 percent, and that of Uzbeks 2.3 percent (Masalsky 1913: 650-651).

In 1926, the population of the Kyrgyz ASSR exceeded its pre-revolutionary level by 13,700 people and reached 1,001,600 (Materials 1926). Different reasons led to the multi-ethnic composition of the population in pre-revolutionary Kyrgyzstan. Thus, Kyrgyz republics had become a new native country for many ethnic groups along with the indigenous population. Summarizing the data provided above, we may conclude that the dynamics of the Kazakh diaspora's growth throughout the period of its formation depended on various factors that affected its relatively small size in comparison to other regions of Central Asia.

\section{KAZAKH REPATRIATES FROM KYRGYZSTAN}

Since Kazakhstan declared its sovereignty, the revival of oralman-repatriates' movement from Central Asia back to their homeland might be observed. The Kazakh diaspora in Kyrgyzstan, as compared with the representatives of other republics, lives relatively well despite the economic difficulties experienced by the country. This is one of the reasons for their slow return to Kazakhstan. Besides, many Kazakhs living in Kyrgyzstan are descendants of refugees, who had suffered from political repressions and economic hardships such as the 1932-1933 famine. Some of the western scholars (Schatz 2004; Dave 2010) often considered the problem of oralmans in the context of the contemporary policy of Kazakhstan, without embedding it in broad migration processes. Edward Schatz mentioned oralmans in his work not through the lenses of migrants but due to their presupposed role in the political struggle for power in Kazakhstan (Schatz 2004). He also referred to B. Dave's work (2010) where the analysis of the repatriates' problems was conducted exclusively in terms of political approach.

In general, Kazakhs in Kyrgyzstan live better than their peers in other countries. However, young Kazakhs have a strong desire to return to their homeland. Statistical data for the period 1989-1998 indicates the return of 2,093 Kazakhs to Kazakhstan (Kalshabayeva 2011). The data shows that 1,224 people had moved to the Dzhambul region, and later on 428 of them moved to towns, and 
796 - to the countryside. The Almaty region attracted fewer repatriates -390 people, whereas 133 of them preferred to settle in urban areas and 257 chose rural districts. The region of southern Kazakhstan received 101 people; 58 of them migrated to urban centers and 43 became rural residents. The Karaganda region was a final destination for 105 repatriates: 89 of them stayed in towns and 16 preferred the countryside. The strength of the new settlers to the region of eastern Kazakhstan is estimated as 90 people, with 69 as urban citizens and 21 as countrymen. Barely few dozens of repatriates have settled in other areas of Kazakhstan (Census 2000: 77-78).

\section{ETHNOGRAPHIC PECULIARITIES OF KYRGYZSTAN KAZAKHS}

Though the customs and traditions of the Middle Asian and Kazakh peoples in the nineteenth century differed from each other, the gist was the same. All these nations shared common origin, history, and language, as for centuries they had been living close to each other. Thus, the similarities in historical development and geographical proximity had shaped some common cultural elements. However, one might observe that there were enough characteristics to demonstrate their cultural and anthropological differences.

In the 1960s-1980s, bride kidnapping was widespread in the regions that were researched by the authors. However, in Kazakhstan we rarely encountered this phenomenon while in Kyrgyzstan we could observe a considerably greater number of bride kidnappings. Unfortunately, among the local Kyrgyz population the old customs and traditions caused real economic difficulties to some in the lower strata of society. In order to reduce their negative impact, bride kidnapping (with the consent of a bride) began to be widely practiced. Surprisingly enough, the Kazakh diaspora in Kyrgyzstan started to follow this practice (Abdibaev Kasen, Field materials 2001). Some of the informants said that the rapid growth of bride kidnapping among Kazakhs had been due in part to the pressure of the Kyrgyz environment (Kalshabayeva 2014: 134-135).

One of the main differences in the traditions related to Kazakhs' marriages in Kyrgyzstan as compared to those in their home country was 'kuyeu tabak'21 of a groom for the bride's sister-in-law ${ }^{22}$. He put 30-100 meters of a very expensive fabric onto it. Until the 1970s, the fabric was tied up around her (sister-in-law's) waist and other women (sisters-in-law) ${ }^{23}$ would untie it and pass around. Additionally, when coming to the bride's house, the groom should have a bar of soap, some perfume, a kerchief or some jewelry in his pocket for the younger sisters of the bride. These traditions are still practiced in all Kazakh-populated regions of Kyrgyzstan (Dastagul Omarovna Mukhanbetova, Field materials 2011). 
Many guests, including the bride's relatives and neighbors, are invited to $k y z$ $u z a t u^{24}$ party. Each of the party attenders contributes to the bride's dowry. They give her various household goods, utensils, and clothing, which are important for the young couple. In earlier times, Kazakhs used to send the bride and her friends to visit the households in the village to invite guests to kyz uzatu, to give her a chance to say goodbye to the relatives.

The Kazakh bride in Kyrgyzstan usually visits her relatives before the wedding party together with her two sisters-in-law. If the bride has no brothers she can be accompanied by her cousins' wives. Her relatives gladly welcome her and give their gifts. Before the bride's sendoff, her parents allow her to take a sightseeing tour of the neighborhood. The whole trip might be videoed and finished with entertaining programs to raise the bride's spirit.

Kazakhs' recitals dedicated to various national holidays and special events are well known in the region. For example, 'zhar-zhar'25 and 'synsyma' and 'synsu' ${ }^{26}$ are still performed by the Kazakh people. Synsu is usually devoted to the girls who were forced into marriage. Synsyma and zhar-zhar were rarely practiced among the Kazakhs in Kyrgyzstan. Usually these recitals were recorded by old people and performed by young Kazakhs just for fun. Today we can see that young people have little interest in such a tradition as synsyma. Here is a synsyma that was recorded by 92-year-old Maken Abisheva from Bishkek:

How hard it is to leave you

My sweet home, my dear friends...

I am more depressed today

Thinking of the forthcoming day

My dear sister, little star,

I will be with you

Wherever you are!

(Abisheva Maken, Field materials 2001)

Traditionally all the community members are invited to the ritual called betashar ${ }^{27}$. Though betashar is an extremely popular ceremony among Kazakhs in Kyrgyzstan, the Kyrgyz tradition of betashar has some differences. The bride is supposed to bow to all the people whose names were mentioned at the opening ceremony. When betashar is over, a man ${ }^{28}$ unveils the bride's face and usually gets a payment for this service (Field materials 2009). If a bride is kidnapped, two smart people from the groom's side are sent to her parents to inform them and to apologize for the young people's behavior. Parents traditionally receive some special gifts called oli'tiri" ${ }^{29}$. A.T. Toleubayev (1991: 214) points out: "Since oli-tiri is dedicated to the bride's deceased relatives, it is usually served as a dish to the aksakals of the village". Argynbayev (1996: 288) also mentioned this tradition in his work. 
Oli-tiri is a widely spread practice of Kazakhs in Kyrgyzstan but they have added some new elements to this tradition. Apart from the sheep, they also give a golden handshake to the bride's parents. ${ }^{30}$ Informant Bugybai Kaliev indicated that the amount of money paid by Argyn-Kazakhs was more than the amount among the Uisun clan. Besides, they also add some sweets and alcohol drinks to oli-tiri; this is the main difference between Kazakhs in Kazakhstan and in Kyrgyzstan. Probably the latter can be explained by the strict alcohol prohibition in Muslim-dominated southern Kazakhstan as compared to the Kyrgyz' indifference towards some important institutions of Islam. The Kyrgyz people call it kuldyk urdyk $k^{31}$.

Nowadays every second marriage in Kyrgyzstan is international/interethnic. The quantity of mixed marriages is relatively high in this country especially among the Kyrgyz and Kazakhs. Kyrgyz researcher Kochkunov commented on the ratio of interethnic marriages: "We have examined 34 mixed marriage families. 28 of them live in Orgochor sovkhoz. 14 of them are Kazakh-Kyrgyz, 3 of them are Uzbek-Kyrgyz, and 2 of them are Kyrgyz-Kalmak' (Zhelokhovtsev 2000: 167). This passage demonstrates that Kazakhs in Kyrgyzstan are more likely to marry representatives of other ethnoses than Kazakhs in Kazakhstan.

When we made a tour in the countryside, nearly every Kazakh family had a daughter-in-law or a son-in-law of Kyrgyz nationality. If this tendency continues, the future generations of our fellow citizens in Kyrgyzstan will become descendants of mixed marriages after a certain period.

Most Kazakh families living in the regions under study still maintain a strong patriarchal society, which is typical for the Kazakh lifestyle. Until the middle of the twentieth century many national wedding traditions and ceremonies had been strongly kept within the region. However, as time passed, these ceremonies - particularly the ones related to weddings - became greatly influenced by the local traditions and customs.

The cradle played and still plays a great role in the upbringing of Muslim people. Kazakhs called it besik, and the first time a baby is put into the cradle was called besikke salu ${ }^{32}$. It was a big event in the life of a child and the parents. I.S. Kolbasenko noted: "In the Tokmak uyezd it was called 'beshik' in Kirgiz" (Kolbasenko 1889). One of the advantages of the Kazakh besik was its comfort; it did not cause any trouble during the journeys; it was very convenient to carry it whenever people moved. In fact, children of nomadic people, particularly Kazakhs, did not suffer from any skin diseases thanks to the besik. Surprisingly, nowadays, the Kazakhs living in Kyrgyzstan do not use the besik at all.

Since the Kazakhs in Kyrgyzstan do not use the besik for a child, they are limited to gift-giving (Field materials 2007). In Kyrgyzstan Kazakhs are illinformed about this tradition. They simply give a gift to a woman who puts 
the baby into the besik. The Kyrgyz people use nine things to cover the besik, while the Tajiks use seven (Bizhanova 2001: 19). When the baby is placed in the besik, an old woman gives it her blessings, wishes good luck to the baby. Before that the young mother, while holding the besik, bows to the guests to express her gratitude to God for having a sweet baby.

One Kyrgyz tradition, which is shared by the Kazakhs in Kyrgyzstan, is the child's visit to the mother's parents to cut the child's hair. It happens when the child reaches the age of three. The grandparents give the child a big present. Kazakhs also have a tradition of giving one of the livestock to a child who visits them for the first time (Bulekbay Tyrybolsynuly Madibekov, Field materials 2011). It is called basire. Some parents leave hair on the back of the child's head. It is called aidar shash. They cut it off only when the child is circumcised.

One of the ceremonies that takes place in the early age of a child is tusau keser. The feet of a child, who makes the first steps, are tied up with a motley string. A small bell is attached to the string. Then a person who is chosen by the child's parents cuts off the string. The string is believed to protect the child from an evil eye, while the bell will make him popular (Field materials 2008). Recently Kazakhs have used some variations of this tradition in Kyrgyzstan. The child's parents organize a 'marathon' ${ }^{33}$ for a group of children, and the one who finishes first will be honored with cutting the string off. Bugybai Kaliev and Marfu Balabekova, residents of the Manas village (Marfu Balabekova, Field materials 2008), say that this tradition originates from the Kyrgyz people. Earlier on, Kazakhs used sheep's intestines instead of a string. It was supposed to bring success to the child. In some regions of Karakalpakstan, koz monshak ${ }^{34}$ replace the string, while in Kyrgyzstan a red ribbon is used instead to make the child walk beautifully (Beysekhan Moldabayev, Field materials 2011).

All traditions and customs related to childbirth and upbringing play a great part in people's lives. The Kazakh people try to educate their children to respect the older and help the younger. Unfortunately, there is one problem still unsolved by the Kazakhs living abroad. It is the problem of the Kazakh language. Kazakh children do not know their mother tongue due to the absence of Kazakh-language schools and the abundance of Russian schools.

All the collected materials demonstrate that there are many similarities in the traditions and customs related to childbirth and upbringing of Kazakhs living in different regions of Central Asia. Though the Kazakh diaspora in the neighboring countries of Central Asia seems to maintain some national traditions and customs, they have gradually changed due to the pressure and influence of the local social institutions. Thus, we may conclude that such ethnographic distinctions and features of the Kazakhs in Central Asia require a serious research. 


\section{RESULTS AND DISCUSSION}

\section{The chronological framework of the history of the Kazakh diaspora formation in Kyrgyzstan}

The main stages of the Kazakhs' settlement in Kyrgyzstan can be divided as follows: the first one is determined by the inter-ethnic contacts existing since the Middle Ages, when the borders of neighboring nomadic tribes were not strictly outlined. The second stage is related to various administrative-territorial reforms of tsarist Russia in the nineteenth and twentieth centuries. The third stage is related to the national territorial demarcation in Central Asia, carried out by the Soviet authorities in the 1920s. All these historical circumstances became the most significant factors in the formation of the Kazakh diaspora in Kyrgyzstan.

The Kazakh diaspora was largely created because of the administrative and enforcement actions of the tsarist empire, based on the principle "divide and rule". Such an event as the exodus of Kazakhs from their ancestral lands in 1916, after the defeat of the national uprising, is an obvious example of the local population's reaction to the tsarist colonial policy. Archival materials depicting how large groups of Kazakh and Kyrgyz population from Almaty, Pishpek, Dzharkent, Lepsinsk, Kopalsk, and other uyezds fled abroad to the neighboring China testified to these migrations. It is not possible to determine the exact number of people who fled due to the events of 1916 and the "red terror" of 1917-1918, but rough estimates show that it was about 100,000 Kazakhs. However, after the establishment of the Soviet power and the land reforms of 1921-1922, many Kazakhs and Kyrgyz returned from China but because they feared to lose their property, they preferred to stay on the lands of Kyrgyz manaps in Issyk-Kul, Pishpek, and Karakul districts. Ethnographic materials collected by the authors confirmed these facts.

\section{Specific features of Kazakhs' resettlement in Kyrgyzstan}

The authors defined the areas of Kazakh settlements in the 1920s, after their return from China, then in the 1930s, after the crop failure and famine, and in the 1960s-1970s, when they came to Kyrgyzstan as labor migrants. So, in 1922, during a four-month period, 307 Kazakh families comprised of 824 people returned to Kyrgyzstan. Most Kazakhs settled in the suburban areas of Bishkek, where they formed centers of compact settlement, such as the villages of Manas, Razdolnoye, Alty Barak, and others.

Such tragic events as the crop failure and famine, food shortages, and other economic hardships, caused a large flow of migrants, who moved from Kazakhstan to Kyrgyzstan in 1932-1933. As a result, by 1939 the percentage 
of the indigenous population - the Kyrgyz - decreased to 51.7 percent, which, in turn, increased the size of other ethnic groups. Therefore, the number of Russians increased to 20.8 percent, and that of Kazakhs - to 1.6 percent. At that time, the number of Kazakhs in Kyrgyzstan was 23,925 (1.6 percent out of the total population of the country). In the 1960s-1970s, due to labor migration, 21,263 people moved from Kazakhstan to Kyrgyzstan. A significant influx of migrants - 5,469 people - came from the Dzhambul region, which is explained by the proximity of the region.

\section{Problems of demarcation of ethnic territories}

The demarcation of the ethnic territory of Kazakhstan and Kyrgyzstan was based on the results of numerous ethnographic expeditions as well as the works of Russian and Soviet orientalists, and Kazakh and Kyrgyz ethnographers. The ethnic-territorial demarcation in the republics of Central Asia caused fierce disputes regarding the partitioning of pastures for grazing and haymaking. For instance, dzhaylyau Susamyr at the Zailisky Alatau foothills was added to Kyrgyz lands and immediately became the subject of contentious conflicts between the neighboring Kyrgyz and Kazakhs. Debates over lands consequently led to the increase of the Kazakh diaspora on the territory of Kyrgyzstan. Another factor that caused the growing number of Kazakhs in Kyrgyzstan is connected with the Kazakhs-Argyns migration from the Akmola region in search of rich pastures at the border of Kyrgyzstan in the late twentieth century. One of the archival documents contained information about the desire of 42 Kazakhs-Argyns' households to stay in the Kyrgyz territory.

\section{The reasons for oralmans' repatriation from Kyrgyzstan}

The total number of repatriates-oralmans to their historic homeland, as compared with the percentage of repatriates from the Kyrgyzstan Republic, is negligible, especially in comparison with diasporas from other regions of Central Asia. It can be explained by the following reasons: first, the relatively stable financial position of Kazakhs in Kyrgyzstan; second, lack of nostalgia due to the close location of both nations' territories. The outflow of Kazakhs from Kyrgyzstan is represented mainly by younger generation, who move to Kazakhstan to settle in economically and culturally more developed megalopolises such as Astana and Almaty.

Though Kazakh people in Kyrgyzstan continue to maintain the traditions and rituals of the native country, they are slowly adopting new practices borrowed from the local population. Meanwhile, widely spread intermarriages between the Kyrgyz and Kazakhs significantly affect the convergence of some social institutions. 


\section{CONCLUSION}

The history of the formation of the Kazakh diaspora in Kyrgyzstan is related to such historical events as the 1916 national-liberation movement, the demarcation of the national territory of ethnic republics in Central Asia in 1924-1928, collectivization, famine and crop failure in 1928 and in 1932-1933, labor migration, and some other factors. Most of the Kazakh people settled on the territory of Kyrgyzstan, which belongs to the Uisun tribe. ${ }^{35}$ They were the first to come back from China. Smaller numbers of Kazakhs were Argyns from Central Kazakhstan (Shet and Karkara regions) together with the other Kazakhs from Semey Oblast (Tobykty and Naiman clans). The second group migrated to Kyrgyzstan after collectivization and crop failures that led to famine and devastation of the farms. In the 1930s, Kazakhs settled in Kyrgyzstan, in the regions of Alameddin, Sokuluk, Manas, Priozernoye, Razdolnaya, Altybarak, and others. Other destination centers were cities of Bishkek, Tokmok, Talas, $\mathrm{Shu}$, and the Tien Shan and Issyk-Kul areas.

Over the past ten years, the Kazakh population in Kyrgyzstan has started to decrease. The main reasons of the Kazakh population's outflow from Kyrgyzstan are socio-economic, spiritual, cultural, and partly political ones, while successful socio-economic development, political stability, and inter-ethnic accord attract our kinsmen to Kazakhstan.

We may still consider the Kazakhs who live in the neighboring regions of Kazakhstan as an indivisible part of the Kazakh ethnos. The most important task of modern Kazakhstan as a sovereign state is to have strong and attractive national idea and effective foreign policy. Studies of migration history, Kazakh culture maintained by our kinsmen abroad, their mentality, ethnic identity, traditions, and lifestyle create a strong foundation for realizing the aims that our state has set for sustainable and prosperous life of our people.

\section{NOTES}

1 Oralmans are Kazakhs who return to Kazakhstan from abroad. They migrated from the native country mainly due to certain political and economic reasons from the eighteenth to the twentieth centuries.

2 Today Kazakhs live in forty countries.

3 Before the revolution of 1917, Kazakhs were called Kyrgyz due to the pre-revolutionary scientific tradition in Russian ethnography. The present population of the Kyrgyz Republic was called Kara-Kyrgyz.

4 A large pasture named Susamyr situated in Kyrgyz and Kazakh republics but used for a long time by the Kazakh nomads.

5 Bishkek, formerly (1862-1926) Pishpek, or Bishkek, and (1926-1991) Frunze. 
6 Administrative unit in tsarist Russia.

7 In the early twentieth century Semirechenskaya Oblast consisted of six uyezds (counties).

8 Kyrgyz was the old name of Kazakhs used in tsarist Russia.

9 Here it means the Kazakh Autonomous Republic of the Russian Soviet Socialist Federative Republic. Kyrgyz means Kazakh.

${ }^{10}$ Kyrgyz aristocracy.

${ }^{11}$ All large pastures had names.

12 They were later integrated into the Kyrgyz Autonomous Region.

${ }^{13}$ Kamyshovskaya village was included in the Kyrgyz region.

14 The middle part of Argyn village was left in the Kazakh ASSR, and was transformed into an enclave because most of the village became part of the Kyrgyz territory.

${ }^{15}$ On average every family had $4-5$ people.

${ }^{16}$ The Dzhambul region borders on the Talas region (Kyrgyzstan).

${ }^{17}$ Modern Almaty region was also called Semirechye.

${ }^{18}$ It was the first time that a census was conducted in Tsarist Russia.

${ }^{19}$ Kazakhs.

${ }^{20}$ Half-Kazakhs.

21 The groom's dish.

${ }^{22}$ Bride's sister-in-law here means the wife of her brother.

${ }^{23}$ Same if the bride has married brothers.

${ }^{24}$ Kyz uzaty means a party when bride's parents say goodbye to their daughter and send her to the groom's family.

${ }^{25}$ A special song performed at the wedding party.

${ }^{26}$ A song performed during kyz uzatu. Synsyma and synsu are different names of one type of song.

${ }^{27}$ Removing the bride's veil.

${ }^{28}$ A specially invited singer who conducts the ceremony.

${ }^{29}$ Sheep.

${ }^{30}$ Ranging from 10,000 to 40,000 tenge (currency in Kazakhstan).

${ }^{31}$ Begging.

${ }^{32}$ Putting in the traditional cradle. 
${ }^{33}$ It is a race but people call it marathon for fun.

${ }^{34}$ Beads that are believed to protect from the evil eye.

${ }^{35}$ The Uisun tribes have populated these lands since the medieval period. They were part of the Senior Zhuz (horde). In the past the Kazakh khanate consisted of three zhuzes (Senior Horde, Middle Horde, and Junior Horde).

\section{ARCHIVAL SOURCES}

CSA RK = Central State Archive of the Republic of Kyrgyzstan:

F. 847 , op. 1, d. 27, pp. 128-129, 136-137

F. 21 , op. 3 , d. 105 , pp. $6-7,69,71,105$

F. 21 , op. 1, S. 5, L. 61,63

F. 21 , op. 5 , p. 6,109

F.105, op. 31 , D. 324 , p. 47

CSA RU = Central State Archive of the Republic of Uzbekistan:

F. r-1, op.1, d. 707, L. 95-96.

F. 1, op. 4, d. L. 1390, pp. 2, 9.

F. r-1, op. 1, d. 707, pp. 94-95.

\section{LIST OF INFORMANTS (FIELD MATERIALS 2001-2011)}

Kaliyev, Bugibay, b. 1927, tribe - Argyn. Village Manas, Kyrgyzstan.

Abdibaev, Kasen, b. 1918, tribe - Argyn. Village Manas, Kyrgyzstan.

Almaganbetova, Ulsara, age 97, tribe - Argyn. Bishkek, Kyrgyzstan.

Mukhanbetova, Dastagul Omarovna, b. 1941, tribe-Argyn. Village Razdolnoye, Kyrgyzstan. Balabekova's Marfu, 72 years old, tribe - Argyn. Village Manas, Kyrgyzstan.

Abisheva, Maken, 98 years old, tribe - Tobykty. Bishkek, Kyrgyzstan.

Madibekov, Bulekbay Tyrybolsynuly, 71 years old, tribe - Tarykty. Village Akzhar, Sokuluk district, Kyrgyzstan.

Kassenova, Azharkul, b. 1928, tribe - Bestorsyk. Village Manas, Kyrgyzstan.

Moldabayev, Beysekhan, b. 1941, tribe - Botbay, Senior Horde (or Great Horde), Bishkek, Kyrgyzstan.

Imanbayeva, Uldana, 83 years old, tribe - Saryuysin, Bishkek, Kyrgyzstan.

Myrzabekova, Gulsara, 78 years old, tribe - Saryuysin. Village Razdolnoye, Kyrgyzstan. Aymukhanbetova, Kulyash, 76 years old, tribe - Botpay. Village Razdolnoye, Kyrgyzstan.

\section{REFERENCES}

All Central Asia 1926 = Vsia Sredniaia Aziia 1926 god. [All Central Asia 1926.] Tashkent: Sredne-Aziatskoe otd. Rossiisko-Vostochnoi torgovoi palaty.

Argynbayev, Khalel 1996. Kazaқ̧ otbasy. [Kazakh Family.] Almaty: Kainar.

Arkhipov, Nikolai 1930. Sredne-Aziatskie respubliki. [Central Asian Republics.] Moscow \& Leningrad: Gos. izd-vo. 
Baltabayeva 2011 = Baltabaeva, Kulgazira. Kazakhi Kyrgyzstana: sravnitel'nyi analiz itogov natsional'nykh perepisei 1999 g. i 2009 g. [Kazakhs of Kyrgyzstan: A Comparative Analysis of the National Censuses' Results in 1999 and 2009.] In: K.N. Baltabaeva \& T.E. Abilova \& E.U. Baidarov \& A.T. Suleimenova (comps.) Natsional'naia ideia - faktor ob"edineniia sootechestvennikov vo blago nezavisimogo Kazakhstana. [National Idea: Factor of Unification of Countrymen for the Benefit of Independent Kazakhstan.] Materialy mezhdunar. nauch.-teor. konf., g. Almaty, 14 sent. 2011 g. Almaty: Atazhurt, pp. 112-118.

Berry, John W. 2003. Conceptual Approaches to Acculturation. In: K. Chun \& P. Balls Organista \& G. Marin (eds.) Acculturation: Advances in Theory, Measurement, and Applied Research. Washington DC: American Psychological Association, pp. 17-37.

Bizhanova, Aliya 2001. Semeino-bytovye obriady kazakhov nizov'ia Amudar'i (vtoraia polovina XIX-seredina XX vv.). [Family and Household Ceremonies in the Lower Reaches of Amu Darya (Second Half of the 19th - Middle of the 20th Centuries).] Avtoreferat dissertatzii na soiskanie stepeni kandidata istoricheskih nauk. Nukus: Nukus State University.

Census 2000 = Rezul'taty perepisi 1999. [Results of the 1999 Census.] Almaty: Statisticheskoe agentstvo.

Dave, Bhavna 2010. Politics of Modern Central Asia: The Changing Geopolitical Context. Abingdon \& New York: Routledge.

Grodekov, Nikolay 1889. Kirgizy i karakirgizy Syr-Dar'inskoi oblasti. [The Kyrgyz and Kara-Kyrgyz of the Syr-Darya Region.] Tashkent: Tipo-lit. S.I. Lakhtina.

Kalshabayeva, Bibiziya 2011. Ortalyқ̧Aziiadazy қ̧azaқ̧tar (tarikhi-etnografiialyқ̧zertteu). [Kazakhs in Central Asia (Ethnographic Research).] Almaty: Қаzaқ universiteti.

Kalshabayeva, Bibiziya 2014. Central Asian Kazakhs (Historical-Ethnographic Research). Almaty: Arys.

Kalshabayeva, Bibizia \& Seisenbayeva, Akbota 2013. Some Problems of Repatriation and Adaptation of Representatives of the Kazakh Diaspora of Central Asia in the Historic Homeland. Middle-East Journal of Scientific Research, Vol. 15, No. 1, pp. 20-26. DOI: 10.5829/idosi.mejsr.2013.15.1.11054.

Karutts 1910 = Karutts, Rikhard. Sredi kirgizov i turkmenov na Mangyshlake. [Among the Kyrgyz and Turkmens in Mangyshlak.] Transl. by E. Petri. St. Petersburg: Izdanie A. F. Devriena.

Koblandin, Kalybek 2008. Sovremennye migratsionnye trendy iz Uzbekistana v Kazakhstan. [Modern Migration Trends from Uzbekistan to Kazakhstan.] Izvestiia NAN RK, No. 2, pp. 43-47. Available at http://nblib.library.kz/elib/ library.kz/journal/\%D0\%9A\%D0\%BE\%D0\%B1\%D0\%BB\%D0\%B0\%D0\%BD\%D 0\%B4\%D0\%B8\%D0\%BD\%20\%D0\%9A.\%D0\%98.\%D0\%B0.pdf, last accessed on 12 July 2019.

Koblandin, Kalybek 2012. Tekushchii arkhiv Vsemirnoi Assotsiatsii kazakhov. [The Current Archive of the World Association of Kazakhs.] Almaty: n.p.

Kolbasenko, Ivan 1889. Nekotorye kirgizskie obychai i pover'ia, imeiushchie akusherskoe znachenie. [Some Kyrgys Customs and Beliefs with Obstetric Value.] Protokoly Kievskogo akushersko-ginekologicheskogo obshchestva, Vol. 5, pp. 47-49.

Krongardt, Gennadiy 1989. Naselenie Kirgizii v poslednei treti XIX-nachale XX veka. [Demographics of Kyrgyzstan in the Last Third of the 19th - Early 20th Centuries.] Frunze: Ilim. 
Masalsky 1913 = Masal'skii, Vladislav (comp.). Rossiia: Polnoe geograficheskoe opisanie nashego otechestva. T. 19: Turkestanskii krai. [Russia: Complete Geographical Description of Our Fatherland. Vol. 19: Turkestan.] St. Petersburg: Izdanie A. F. Devriena. Available at http://elib.shpl.ru/ru/nodes/170-t-19-turkestanskiykray-1913, last accessed on 12 July 2019.

Materials 1926 = Materialy po raionirovaniiu Uzbekistana. [Materials on the Zoning of Uzbekistan.] Vol. 1. Samarkand: n.p.

Materials $1927=$ Materialy komissii ekspeditsionnykh issledovanii AN SSR: Osobennosti sel'skogo khoziaistva Adaevkogo uezda. Issledovanie $1926 \mathrm{~g}$. [Materials of Commissions of Research Expeditions of the Academy of Sciences of the USSR: Agriculture of Adaevsky Uyezd. Research of 1926.] Vol. VI. Tashkent: n.p.

Mendikulova, Gulnara 1997. Istoricheskie sud'by kazakhskoi diaspory. Proiskhozhdenie i razvitie. [Historical Destiny of Kazakh Diaspora: Origin and Development.] Almaty: Gylym. Available at http://bibliotekar.kz/istoricheskie-sudby-kazahskoidiaspory-g, last accessed on 12 July 2019.

Mendikulova, Gulnara 2006. Kazakhskaia diaspora: istoriia i sovremennost'. [Kazakh Diaspora: Past and Present.] Almaty: Reis.

Pallas 1778 = Pallas, Petr S. Puteshestvie po raznym provintsiiam Rossiskogo gosudarstva. [Travelling to Different Provinces of the Russian State.] Vol. 2. St. Petersburg: Imperatorskaia Akademiia Nauk.

Pashino, Petr 1868. Turkestanskii krai v 1866 godu. Putevye zametki. [Turkestan in 1866. Travel Notes.] St. Petersburg: Tip. Tiblena i Nekliudova.

Sartbayev 2009 = Sartbaev, Maksut. Kazakhi Kyrgyzstana. Proshloe i nastoiashchee. [Kazakhs of Kyrgyzstan: Past and Present.] Bishkek: Ilim.

Schatz, Edward 2004. Modern Clan Politics: The Power of "Blood" in Kazakhstan and Beyond. Seattle: University of Washington Press.

Shalekenov, Uakhit 1966. Kazakhi nizov'ev Amu-Dar'i. K istorii vzaimootnoshenii narodov Karakalpakii $v$ XVIII-XX vv. [Kazakhs of the Lower Reaches of Amu Darya River: To the History of the Relationship of Karakalpakastan Peoples in the 18th-19th cc.] Tashkent: Fan.

Sheffer, Gabriel 1986. Modern Diasporas in International Politics. London: Croom Helm.

Statistical Data 2001 = Statistical data obtained from the Statistics Department of the Kyrgyz Republic in 2001 (in possession of the author).

Svanberg, Ingvar 1989. Kazak Refugees in Turkey: A Study of Cultural Persistence and Social Change. Uppsala: Academiae Ubsaliensis.

Tatimov, Makash 1992. Khalyқ̧nama nemese san men sana. [Folklore or Number and Consciousness.] Almaty: Zhazushy.

Toleubayev 1991 = Toleubaev, Abdesh. Relikty doislamskikh verovanii $v$ semeinoi obriadnosti kazakhov (XIX-nachalo XX v). [Relics of Pre-Islamic Beliefs in Family Rites of the Kazakhs (19th and Beginning of the 20th Centuries).] Almaty: Gylym.

Zhelokhovtsev, V.S. 1989. Izmenenie etnicheskogo sostava naseleniia Kirgizii (20-30-e gody $\mathrm{XX} v$ ). [Changes in the Ethnic Composition of the Population of Kyrgyzstan (20s-30s of the 20th Century).] In: Aktual'nye problemy etnografii i arkheologii Kyrgyzstana. Collection of articles. Frunze: Izdatel'stvo Akademii nauk Kyrgyzskoi SSR. Zhelokhovtsev, V.S. 2000. Naselenie Kirgizii. [Population of Kyrgystan.] Bishkek: n.p. Yearbook 1924 = Statisticheskii ezhegodnik 1917-1923. [Statistical Yearbook 1917-1923.] Vol. 1. Tashkent: Tsentral'noe statisticheskoe upravlenie Turkrespubliki. Available at http://libarch.nmu.org.ua/handle/GenofondUA/24292, last accessed on 15 July 2019. 